\title{
Mass-balance estimates on the glacier complex Kongsvegen and Sveabreen, Spitsbergen, Svalbard, using radioactive layers
}

\author{
BERNARD LEFAUCONNIER, \\ Laboratoire de Glaciologie et Géophysique de l'Environnement, 38402 Saint-Martin d'Hères Cedex, France, \\ and Norsk Polarinstitutt, 1330 Oslo Lufthavn, Norway \\ Jon Ove Hagen \\ Norsk Polarinstitutt, 1330 Oslo Lufthavn, Norway \\ Jean Francis Pinglot and Michel Pourchet \\ Laboratoire de Glaciologie et Géophysique de l'Environnement, 38402 Saint-Martin d'Hères Cedex, France
}

\begin{abstract}
Analyses of total $\beta$ and $\gamma$ radioactivity have been carried out on ten shallow ice cores collected in 1989 and 1990 on Kongsvegen and Sveabreen, Spitsbergen. No peak of total $\beta$ radioactivity, corresponding to the Chernobyl accident (1986), can be identified. Chernobyl layers were identified by ${ }^{137} \mathrm{Cs}$ and ${ }^{134} \mathrm{Cs}$ activities, and a signal from the nuclear tests in Novaya Zemlya (1961-62), was detected at one location by ${ }^{137} \mathrm{Cs}$ activity. The mean net accumulation for the periods 1986-89 and 1962-88 was estimated for both glaciers. Using topographic data, the mean net ablation on Kongsvegen was estimated for the period 1964-90 and the mean net balances were calculated. The results agree with recent direct glaciological balance measurements. For the period 1986-89, the net accumulation was higher on Sveabreen than on Kongsvegen, and the equilibrium-line altitudes (ELA) were around 450 and $520 \mathrm{~m}$ a.s.l., respectively. Kongsvegen had a positive balance of $0.11 \mathrm{~m}$ w.eq. and Sveabreen was in equilibrium, whereas for the last 26 years the balance of Kongsvegen was slightly negative $(-0.10 \mathrm{~m}$ w.eq. $)$ and the ELA was around $560 \mathrm{~m}$ a.s.l.
\end{abstract}

\section{INTRODUCTION}

Following the Chernobyl accident on the 26 April 1986, it has been shown that a new well-known radioactive reference level allows snow and ice dating in the Northern Hemisphere, as the fall-out of radioactive elements has been detected in Greenland, Scandinavia, the Alps and Svalbard. In Svalbard, radioactivity was detected at $\mathrm{Ny}-$ Alesund, in the vicinity of the presently studied glaciers (Pourchet and others, 1986, 1988) and at Austfonna in Nordaustlandet, eastern Svalbard (Vaykmyae and Punning, 1989). This reference level allows determination of net glacier balances in the accumulation area (Pinglot and Pourchet, 1989) as well as the amount of radioactive fall-out. In Nordaustlandet, the amount of radioactivity due to atmospheric nuclear tests conducted in 1961 and 1962 , mainly by the U.S.S.R. in Novaya Zemlya $\left(75^{\circ} \mathrm{N}\right.$, $55^{\circ} \mathrm{E}$ ), has also been obtained (Punning and others, 1986; Vaykmyae and Punning, 1989).

The aim of the present work is to describe an analysis of radioactivity in shallow ice cores on Kongsvegen and Sveabreen to identify the Chernobyl layer, and thus the 3 year mean net balance in the accumulation area. Since 1986-87, the annual balance of Kongsvegen has been determined by the Norsk Polarinstitutt using direct glaciological measurements (Hagen and Liestøl, 1990). Thus, the net balance obtained using the Chernobyl layer can be compared and corroborated with these direct measurements. The detection of the 1962 radioactive layer (following the 1961-62 tests) in one location on Kongsvegen allows estimation of the net balance in the accumulation area of both glaciers for the period 1962 88. On Kongsvegen, topographic work done in the ablation area in 1964 and 1991 allows estimation of the net balance in the ablation area between these two dates. Thus, the balance and the equilibrium-line altitude (ELA) on both Kongvegen and Sveabreen for a period of 26 years may be estimated and compared with the 3 years' period (1986-89).

\section{BACKGROUND}

The glacier complex formed by Kongsvegen and Sveabreen is situated in west Spitsbergen between $78^{\circ} 30^{\prime}$ and $78^{\circ} 50^{\prime} \mathrm{N}$ (Fig. 1). From a common summit (Kongsvegpasset, $726 \mathrm{~m}$ a.s.l.), the two glaciers flow in opposite directions along an axis oriented southeast-northwest. 


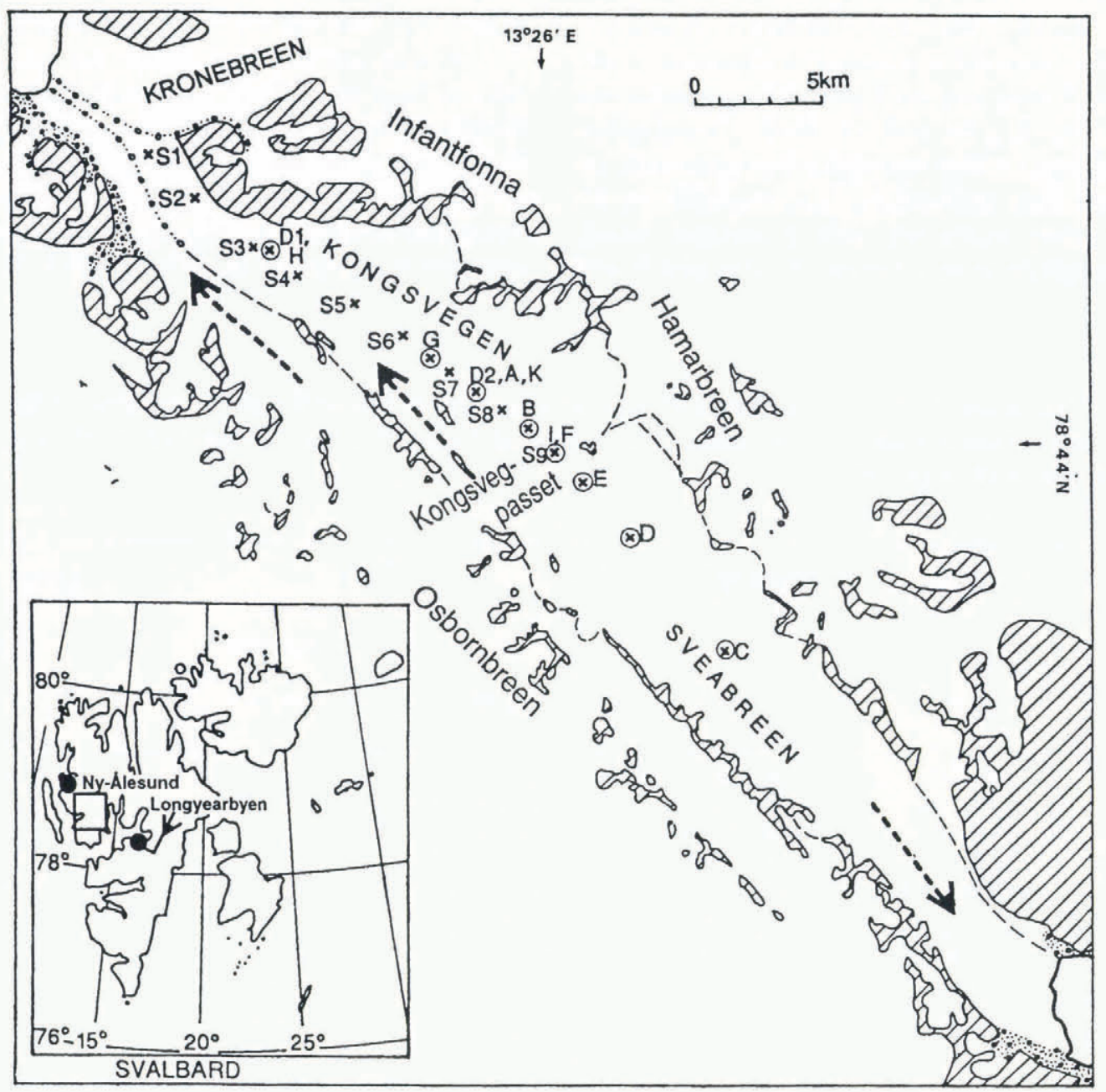

Fig. 1. The glacier complex Kongsvegen/Sveabreen. Crosses are sites of investigation mentioned in the text. S1, S2 ...S9 represent ablation stakes and $D 1, D 2$ indicate ablation stakes at drilling points. Locations of ice cores $(A, B \ldots I$ and $K)$ are shown by circles. Dash lines indicate the limit of the basins and arrows are the main flow directions.

Kongsvegen calves to the north in Kongsfjord and Sveabreen to the south in Isfjord. The glaciers are of comparable size with areas of 102 and $145 \mathrm{~km}^{2}$ and lengths of 26 and $29 \mathrm{~km}$, respectively. According to the wind roses from Ny-Ålesund and Longyearbyen (see location in Figure 1), published by the Norwegian Meteorological Institute (Steffensen, 1982; HanssenBauer and others, 1990), the main snowfalls occur with southeast winds, along the axes of the glaciers. At the NyÅlesund station located $7 \mathrm{~m}$ a.s.l. and $25 \mathrm{~km}$ northwest of the front of Kongsvegen, there is an annual average of 387 positive degree-days (PDD), while at Kongsvegpasset, on a small nunatak $90 \mathrm{~m}$ above the glacier top (i.e. at $815 \mathrm{~m}$ a.s.1.), 45 PDD were recorded in 1990, a year for which the ablation was higher than the mean value.

The glaciers studied have a sub-polar thermal regime, with a temperate firn area and cold upper layers in the ablation area. Temperature profiles down to bedrock in the accumulation and ablation areas confirm the subpolar nature of Kongsvegen (paper in preparation by J. O. Hagen). Temperature measurements at every icecore location were also made during the present work and show that, in the accumulation area of both glaciers, the temperature reaches $0^{\circ} \mathrm{C}$ at about $10 \mathrm{~m}$ depth. Along the longitudinal axis of Kongsvegen, the measured flow velocity is around $2 \mathrm{~m}_{\text {year }}^{-1}$.
Both glaciers in this study are surge-type. The last maximum extension of Sveabreen occurred late in the last century (Salvigsen and others, 1990); since then, its front has retreated more than $3 \mathrm{~km}$. The present calving rate is not known but the topography at the glacier front indicates that, in some years, the front will be mainly on land. Kongsvegen has a common front (named Kongsbreen) with Kronebreen, which had an important surge in 1869. This surge affected the tongue of Kongsvegen which was displaced more than $1 \mathrm{~km}$ into the sea. The following retreat was interrupted in 1948 by a surge of Kongsvegen itself which advanced almost $1.5 \mathrm{~km}$ into the sea. Since then, the glacier front has retreated about $4 \mathrm{~km}$ and, at present, the flow of Kronebreen compresses and blocks the front of Kongsvegen which is now $300 \mathrm{~m}$ wide and has an annual calving rate of only $1 \times 10^{6} \mathrm{~m}^{3}$, corresponding to melting of $1 \mathrm{~cm}$ water equivalent over the whole glacier surface.

\section{METHODS}

\subsection{Determination of radioactive layers}

The Chernobyl accident occurred on 26 April 1986 and incoming radioactivity was noted in Svalbard by 
Pourchet and others (1986). On Austfonna (Nordaustlandet), the first snowfall containing radioactive elements occurred on 4 May and was followed by precipitation events on 10, 11, 17, 18 and 25 May. Precipitation occurring on 10 and 11 May was highly contaminated. In Ny-Ålesund, the first radioactivity was recorded on 13 May in fresh snow which fell with a southern wind. Thereafter, precipitation occurred on 20 May and 3 and
4 June but was not analysed. Meteorological records at $\mathrm{Ny}$-Ålesund indicate that except for $4 \mathrm{~d}$, the period 10 May-6 June was almost completely cloud-covered. It is therefore likely that radioactive snowfalls occurred in the Kongsvegen and Sveabreen basins during this period.

The first ice core ( $\mathrm{K}$ in Fig. 1), to a depth of $20.65 \mathrm{~m}$, was taken in 1989 at an altitude of $639 \mathrm{~m}$ on Kongsvegen, and nine ice cores (A, B ... I in Figure 1; Tables 1 and 2)

Table $1 .{ }^{137} \mathrm{Cs}$ activities and deposited amounts vs depths at all stations. In column 6 , layer $A$ corresponds to the ablation surface from 1989 and is equivalent to the 1988-89 winter-snow deposit, layers $B$ and $C$ correspond to the ablation surfaces from 1986 and 1962, respectively

\begin{tabular}{|c|c|c|c|c|c|}
\hline Station & Depth & Water eq. & & & Layers $(A, B, C)$ \\
\hline ma.s.l. & $\mathrm{cm}$ & $\mathrm{cm}$ & $\mathrm{Bq} \cdot \mathrm{kg}^{-1}$ & $\mathrm{~Bq} \cdot \mathrm{m}^{-2}$ & $\mathrm{~cm}$ \\
\hline $\begin{array}{l}\mathrm{K}-1989 \\
(639 \mathrm{~m})\end{array}$ & $\begin{array}{c}260-590 \\
1295-1482 \\
1482-1674 \\
1674-1875 \\
1875-2065\end{array}$ & $\begin{array}{c}88-163 \\
742-874 \\
874-1035 \\
1035-1216 \\
1216-1382\end{array}$ & $\begin{array}{r}1.41 \times 10^{-3} \\
3.16 \times 10^{-3} \\
5.86 \times 10^{-3} \\
7.55 \times 10^{-3} \\
22.09 \times 10^{-3}\end{array}$ & & $\begin{array}{l}A=260 \\
B=382 \\
C=1875\end{array}$ \\
\hline A $(636 \mathrm{~m})$ & $\begin{array}{r}0-453 \\
453-493 \\
493-550 \\
550-600 \\
600-708 \\
0-708\end{array}$ & $\begin{array}{r}0-191 \\
191-213 \\
213-245 \\
245-273 \\
273-337\end{array}$ & $\begin{array}{r}0.37 \times 10^{-3} \\
12.74 \times 10^{-3} \\
11.62 \times 10^{-3} \\
15.25 \times 10^{-3} \\
4.29 \times 10^{-3}\end{array}$ & $\begin{array}{r}0.71 \\
2.80 \\
3.72 \\
4.27 \\
2.75 \\
14.25\end{array}$ & $\begin{array}{l}A=175 \\
B=453\end{array}$ \\
\hline B $(680 \mathrm{~m})$ & $\begin{array}{r}0-481 \\
481-594 \\
594-712 \\
0-712\end{array}$ & $\begin{array}{r}0-222 \\
222-288 \\
288-356\end{array}$ & $\begin{array}{l}0.00 \times 10^{-3} \\
0.00 \times 10^{-3} \\
2.27 \times 10^{-3}\end{array}$ & $\begin{array}{l}0.00 \\
0.00 \\
1.54 \\
1.54\end{array}$ & $\begin{array}{l}A=195 \\
B=594\end{array}$ \\
\hline $\mathrm{C}(538 \mathrm{~m})$ & $\begin{array}{r}0-303 \\
303-380 \\
380-481 \\
481-591 \\
591-748 \\
0-748\end{array}$ & $\begin{array}{r}0-115 \\
115-152 \\
152-204 \\
204-261 \\
261-373\end{array}$ & $\begin{array}{l}0.75 \times 10^{-3} \\
0.00 \times 10^{-3} \\
8.38 \times 10^{-3} \\
4.74 \times 10^{-3} \\
3.80 \times 10^{-3}\end{array}$ & $\begin{array}{l}0.86 \\
0.00 \\
4.36 \\
2.71 \\
4.26\end{array}$ & $\begin{array}{l}A=242 \\
B=380\end{array}$ \\
\hline $\mathrm{D}(617 \mathrm{~m})$ & $\begin{array}{l}223-423 \\
423-591 \\
591-627 \\
627-748 \\
223-748\end{array}$ & $\begin{array}{r}74-175 \\
175-271 \\
271-297 \\
297-375\end{array}$ & $\begin{array}{l}0.00 \times 10^{-3} \\
0.00 \times 10^{-3} \\
0.00 \times 10^{-3} \\
5.66 \times 10^{-3}\end{array}$ & $\begin{array}{l}0.00 \\
0.00 \\
0.00 \\
5.89 \\
5.89\end{array}$ & $\begin{array}{l}A=241 \\
B=627\end{array}$ \\
\hline $\mathrm{E}(658 \mathrm{~m})$ & $\begin{array}{l}244-420 \\
420-547 \\
547-640 \\
640-721 \\
244-721\end{array}$ & $\begin{array}{r}95-189 \\
189-259 \\
259-314 \\
314-363\end{array}$ & $\begin{array}{l}1.29 \times 10^{-3} \\
0.00 \times 10^{-3} \\
3.88 \times 10^{-3} \\
9.29 \times 10^{-3}\end{array}$ & $\begin{array}{l}1.21 \\
0.00 \\
2.13 \\
4.55 \\
7.89\end{array}$ & $\begin{array}{l}A=244 \\
B=547\end{array}$ \\
\hline $\mathrm{F}(726 \mathrm{~m})$ & $\begin{array}{r}0-575 \\
575-618 \\
618-713 \\
0-713\end{array}$ & $\begin{array}{r}0-263 \\
263-291 \\
291-347\end{array}$ & $\begin{array}{r}0.00 \times 10^{-3} \\
8.43 \times 10^{-3} \\
26.47 \times 10^{-3}\end{array}$ & $\begin{array}{r}0.00 \\
2.36 \\
14.82 \\
17.18\end{array}$ & $\begin{array}{l}A=210 \\
B=575\end{array}$ \\
\hline $\mathrm{G}(562 \mathrm{~m})$ & $\begin{array}{l}172-230 \\
230-269 \\
269-335 \\
335-404 \\
404-517 \\
172-517\end{array}$ & $\begin{array}{r}56-108 \\
108-143 \\
143-203 \\
203-265 \\
265-368\end{array}$ & $\begin{array}{l}0.00 \times 10^{-3} \\
5.89 \times 10^{-3} \\
6.30 \times 10^{-3} \\
6.08 \times 10^{-3} \\
3.35 \times 10^{-3}\end{array}$ & $\begin{array}{r}0.00 \\
2.06 \\
3.78 \\
3.77 \\
3.68 \\
13.29\end{array}$ & $\begin{array}{l}\mathrm{A}=172 \\
\mathrm{~B}=230\end{array}$ \\
\hline $\mathrm{H}(390 \mathrm{~m})$ & $132-192$ & $106-161$ & $375 \times 10^{-3}$ & 206.25 & $A=132$ \\
\hline I $(726 \mathrm{~m})$ & $\begin{array}{r}178-591 \\
591-684 \\
684-893 \\
893-1210 \\
178-1210\end{array}$ & $\begin{array}{r}59-261 \\
261-318 \\
318-464 \\
464-681\end{array}$ & $\begin{array}{r}0.14 \times 10^{-3} \\
17.52 \times 10^{-3} \\
3.65 \times 10^{-3} \\
1.19 \times 10^{-3}\end{array}$ & $\begin{array}{r}0.29 \\
11.56 \\
5.40 \\
2.64 \\
19.90\end{array}$ & $\begin{array}{l}A=268 \\
B=591\end{array}$ \\
\hline
\end{tabular}


Table 2. Mean values of measured and estimated net balances in $m$ of water equivalent. The altitudes in italics in column 2 are the estimated mean altitudes between 1964 and 1990. The methods which have been used for measurement or estimation are noted in column 6: "direct" = direct method by stake reading and density measurement, "geodetic" = lowering of the surface from topographic work in the ablation area, "index" = from detected layers with ${ }^{137} \mathrm{Cs}$ activity to the 1989 ablation surface

\begin{tabular}{|c|c|c|c|c|c|}
\hline \multirow[t]{3}{*}{ Glacier } & \multirow{3}{*}{$\begin{array}{l}\text { Altitude } \\
\text { m a.s.l. }\end{array}$} & \multirow{3}{*}{ Station } & \multicolumn{2}{|c|}{ bn (annual average) } & \multirow[t]{3}{*}{ Method } \\
\hline & & & \multicolumn{2}{|c|}{ m w.eq. } & \\
\hline & & & 1986-89 & $\begin{array}{l}1962-88^{*} \\
1964-90^{* *}\end{array}$ & \\
\hline & 198 & S1 & -1.27 & & Direct \\
\hline & 216 & S1 & & $-1.43^{* *}$ & Geodetic \\
\hline & 263 & S2 & -0.99 & & Direct \\
\hline & 277 & S2 & & $-1.13^{* *}$ & Geodetic \\
\hline & 349 & S3 & -0.74 & & Direct \\
\hline $\mathrm{K}$ & 360 & S3 & & $-0.91^{* *}$ & Geodetic \\
\hline $\mathrm{O}$ & 368 & D1 & -0.64 & & Direct \\
\hline $\mathrm{N}$ & 377 & D1 & & $-0.87^{* *}$ & Geodetic \\
\hline G & 415 & S4 & -0.39 & & Direct \\
\hline $\mathrm{S}$ & 418 & S4 & & $-0.62^{* *}$ & Geodetic \\
\hline V & 477 & S5 & -0.14 & & Direct \\
\hline $\mathrm{E}$ & 480 & S5 & & $-0.30^{* *}$ & Geodetic \\
\hline G & 538 & S6 & 0.1 & & Direct \\
\hline $\mathrm{E}$ & 539 & S6 & & $-0.10^{* *}$ & Geodetic \\
\hline \multirow[t]{8}{*}{$\mathrm{N}$} & 562 & G & $0.17 / 0.29$ & & Index \\
\hline & 595 & S7 & 0.35 & & Direct \\
\hline & 636 & A & $0.45 / 0.52$ & & Index \\
\hline & 636 & D2 & 0.48 & & Direct \\
\hline & 639 & $\mathrm{~K}$ & & $0.43 !$ & Index \\
\hline & & & & $0.50^{*}$ & \\
\hline & 666 & S8 & 0.56 & & Direct \\
\hline & 680 & B & $0.70 / 0.79$ & & Index \\
\hline \multirow{3}{*}{$\begin{array}{c}\text { Kongsveg- } \\
\text { passet }\end{array}$} & -726 & S9 & 0.62 & & Direct \\
\hline & 726 & 1 & $0.58 / 0.64$ & & Index \\
\hline & 726 & $\mathrm{~F}$ & $0.61 / 0.70$ & & Index \\
\hline \multirow{3}{*}{$\begin{array}{l}\text { Svea- } \\
\text { breen }\end{array}$} & 658 & $\mathrm{E}$ & $0.54 / 0.71$ & & Index \\
\hline & 617 & D & $0.70 / 0.91$ & & Index \\
\hline & 538 & C & $0.23 / 0.37$ & & Index \\
\hline
\end{tabular}

* values for 1962-88.

**alues for 1964-90.

were taken in April 1990 on Kongsvegen and Sveabreen. The ice cores were obtained in the accumulation area to depths between 7 and $12 \mathrm{~m}$ and one in the upper part of the ablation area to a depth of only $5 \mathrm{~m}$. Each ice core was cut into sections approximately $15 \mathrm{~cm}$ long (almost ten samples for one accumulation year), with an average mass of $300-400 \mathrm{~g}$. After density measurement, these samples were melted and filtered according to the method described by Delmas and Pourchet (1977). The radio- active species were extracted on to ion exchange filters in the laboratory (Pinglot and Pourchet, 1979, 1989). The total $\beta$ radioactivitiy was measured on individual filters and ${ }^{137} \mathrm{Cs}$ was detected using $\gamma$ spectrometry on composited samples.

\subsection{Measurement of total $\beta$ radioactivity}

The measurement of total $\beta$ radioactivity was carried out on samples of all ice cores. This measurement includes but does not discriminate between the total $\beta$ radiation emitted by natural (cosmogenic and terrestrial) and artificial isotopes (fission products from atmospheric nuclear tests, accidents in power stations, etc.). Some years after their emission, the main artificial sources of $\beta$ radiation are ${ }^{90} \mathrm{Sr}$ and ${ }^{137} \mathrm{Cs}$, the latter emitting also $\gamma$ radiation.

The total $\beta$ radioactivity profiles (see Fig. 2) do not show clearly characteristic peaks which can be absolutely attributed to the fall-out of Chernobyl elements. This is due to the fact that the natural total $\beta$ radioactivity is about 10 times the artificial radioactivity. Between the surface and about $2.5 \mathrm{~m}$ depth at stations A, B, C, F and $\mathrm{I}$, the winter snow shows a total $\beta$ radioactivity level constantly higher than $200 \mathrm{dph} \mathrm{kg}^{-1}$. This activity is due to terrestrial and cosmogenic radio-isotopes, mostly of short half-lives, from ${ }^{238} \mathrm{U}$ and ${ }^{232} \mathrm{Th}$ series, as well as ${ }^{40} \mathrm{~K}$, etc. Below this winter deposit (noted A in column 6 of Table 1), the profiles from the previously mentioned stations clearly exhibit individual peaks which may correspond to different summer layers, because it is during this period that the local outcrops are free of snow and surface dust is exposed to aeolian transport and also because the radio-isotopes may become concentrated near the ablation surface.

\subsection{Measurement of the $\gamma$ radioactivity}

To determine the 1986 Chernobyl reference level, $\gamma$ spectrometry has been carried out on all ice cores. The samples were analysed in groups because this technique of measurement is less sensitive than total $\beta$ counting. The re-grouping was made around the previously described individual $\beta$ peaks.

The Chernobyl evidence is based on our measurements of ${ }^{137} \mathrm{Cs}$ and ${ }^{134} \mathrm{Cs}$. The spectrometry of these elements was carried out using a high-purity germanium diode of $\mathrm{N}$ type. This detector has a relative efficiency of $20 \%$. It is made of material free of radioactivity and located at the centre of nuclear shielding in a special building, free from all parasitic radioactivities such as cosmic rays, radon emanations, $\gamma$ rays from building materials, etc.

Whilst the detection of ${ }^{134} \mathrm{Cs}$ confirms the local Chernobyl fall-out, the work has been focused on the ${ }^{137} \mathrm{Cs}$ activity (see Table 1 and Fig. 2). From the snow surface down to a definite depth, the caesium content is zero or insignificant (below detection level, which is about $10 \mathrm{dph} \mathrm{kg}^{-1}$ or $3 \times 10^{-3} \mathrm{~Bq} \mathrm{~kg}^{-1}$ at $95 \%$ confidence level). Thereafter, for every ice core, the caesium level exceeds the minimum detection level. A positive identification of ${ }^{137} \mathrm{Cs}$ indicates the presence of snow contaminated by Chernobyl even though, due to percolation, the max- 

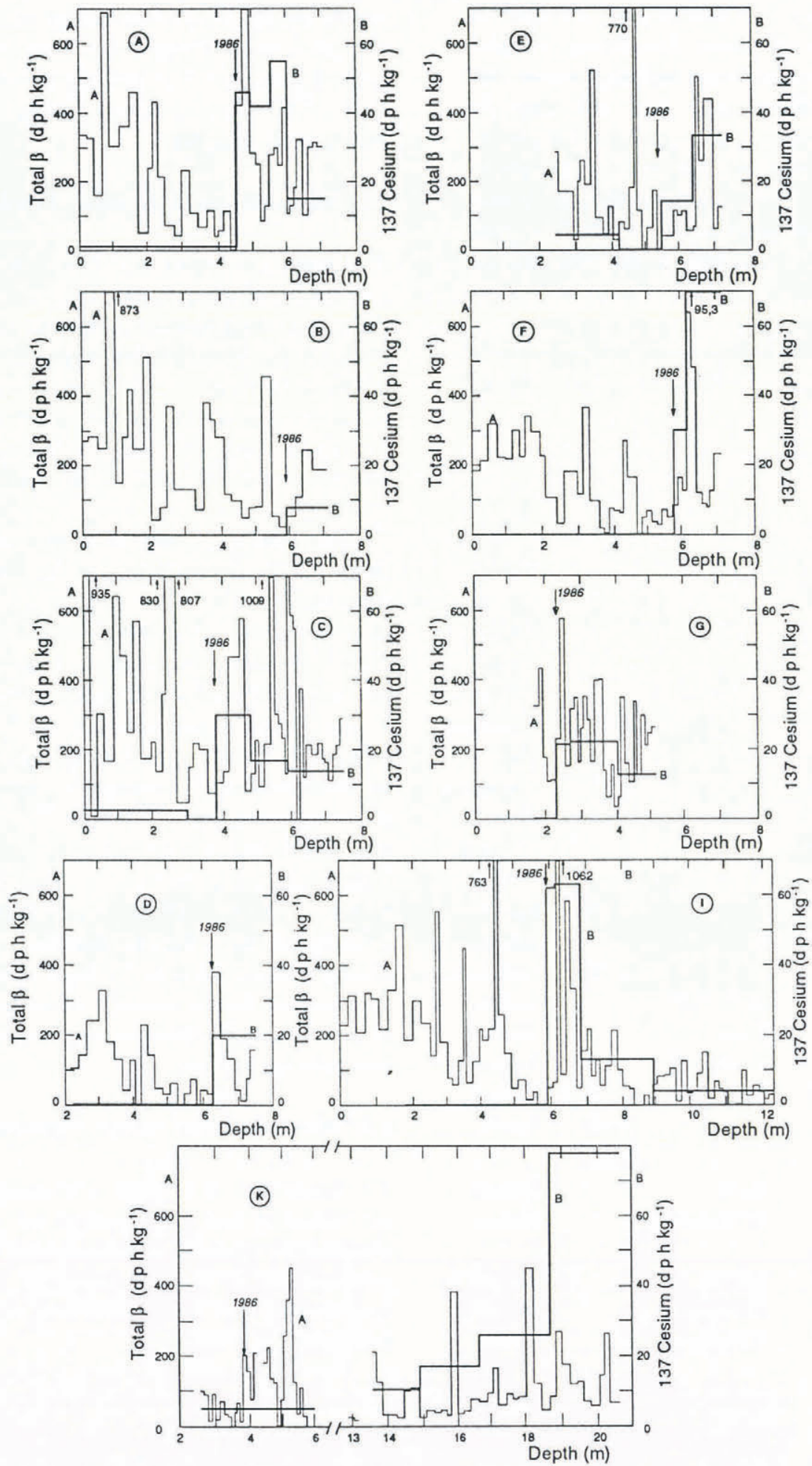

Fig. 2. Total $\beta$ activity (thin lines) and ${ }^{137}$ Cs activity (thick lines) versus depth, at all stations in accumulation areas.

imum activity may be located lower down. This assessment agrees with previous work by Ambach and others (1989).

Ice core I (726 ma.s.l. and $12 \mathrm{~m}$ depth), collected at Kongsvegpasset, provides the best reference data on the Chernobyl layer of May 1986 and allows the determination of total deposition of ${ }^{137} \mathrm{Cs}$. Even at this station, which is the highest point on the glacier, some impurities have migrated downward into deeper layers by percolation, and ${ }^{137} \mathrm{Cs}$ is found $2-3 \mathrm{~m}$ below the reference level of May 1986. The total ${ }^{137} \mathrm{Cs}$ fall-out measured is 20
$\mathrm{Bq} \mathrm{m}^{-2}$, which is similar to fall-outs measured in Greenland (Pourchet and others, 1986; Davidson and others, 1987; Dibb, 1989) ranging from 10 to $20 \mathrm{~Bq} \mathrm{~m}^{-2}$ in the northernmost part (between $77^{\circ}$ and $81^{\circ} \mathrm{N}$ ) and at the highest location (Summit station). These values are, however, much lower than the fall-outs measured in Alpine glaciers (Ambach and others, 1987; Haeberli and others, 1988). At all other stations, the ice cores do not penetrate deep enough and therefore we have only partial fall-out results. Ice core $\mathrm{H}$ at $390 \mathrm{~m}$ a.s.l., in the ablation area, shows a high concentration of radioactive elements 
at the glacier surface. At this location, the successive radioactive layers deposited since the first atmospheric tests are concentrated at the ice surface.

Ice core $\mathrm{K}$ ( $639 \mathrm{~m}$ a.s.l. and $20.65 \mathrm{~m}$ deep) was taken in 1989 mainly for use as a test; thus, the radioactive profile is not continuous and samples between 5.90 and $12.95 \mathrm{~m}$ were not analysed. Nevertheless, its $\gamma$ profile shows two steps of radioactivity at 14.82 and $16.74 \mathrm{~m}$; then, a further step from 18.75 to $20.65 \mathrm{~m}$ which reaches a ${ }^{137} \mathrm{Cs}$ activity of $80 \mathrm{dph} \mathrm{kg}^{-1}$. This activity is around 8 times the activity of the samples located between 12 and $15 \mathrm{~m}$, and may be attributed to the last important nuclear tests conducted in 1961 and 1962, especially by the U.S.S.R. in Novaya Zemlya $\left(75^{\circ} \mathrm{N}, 55^{\circ} \mathrm{E}\right)$. Comparison with total $\beta$ profiles obtained in Nordaustlandet (Vaykmyae and Punning, 1989) and at Station Central in Greenland (Holdsworth and others, 1984) (used here as references), suggests that the samples from $18.65 \mathrm{~m}$ depth correspond to the year 1962. Radioactive profiles from an ice core of $24 \mathrm{~m}$ collected on top of Kongsvegen in April 1992 (Pinglot and others, 1992) and from an ice core of $26.80 \mathrm{~m}$ depth, collected nearby at the same time, have recently confirmed this conclusion.

\subsection{Kongsvegen balance from the direct glacio- logical method}

The mass balance of Kongsvegen has also been obtained since $1986-87$ by stake measurements, snow-depth sounding profiles and density measurements in pits along the glacier. There are nine stakes from the summit at $726 \mathrm{~m}$ a.s.l. down to $198 \mathrm{~m}$ (S9, S8 ... S1 in Figure 1; stake altitudes in Table 2). Soundings were made every $200 \mathrm{~m}$. At the end of the ablation period, density of the firn was determined in two pits, one at the summit and one around $620 \mathrm{~m}$ a.s.l. Net accumulation close to the equilibrium line consists only of superimposed ice.

As mentioned previously, the calving of Kongsvegen is very small (less than $2 \%$ of the ablation by melting). Nevertheless, this calving is taken into account in the results in Table 2. The mean annual balance in the 3 years $1986-89$ is positive $(0.11 \mathrm{~m}$ w.eq.; Table 3$)$, mainly due to a higher positive value in 1987. Hagen and Liestøl (1990) have measured the balances of Brøggerbreen, a small glacier in the vicinity of Kongsvegen, since 1967 and their result is also presented in Table 3. There is consistency in the change of the balance of both glaciers.

\section{RESULTS AND DISGUSSION}

\subsection{Definition of the periods}

Fall-out of Chernobyl elements occurred in May 1986. Following this event, there was negligible precipitation until the beginning of the ablation period which started in June. In Ny-Ålesund, the atmospheric temperature rose by $5^{\circ} \mathrm{C}$ up to 1 June and only $14 \mathrm{~mm}$ of rain was recorded during this month. Thus, the Chernobyl horizon corresponds to the ablation surface from 1986. Nuclear tests in 1962 in Novaya Zemlya occurred between August and December. In the present work, we link this horizon to the 1962 ablation surface, even though the upper part of this horizon could be included within the snow layer from the 1962-63 winter. The introduced uncertainty is small as the calculations will be carried out using a period of 26 years.

The sampling used in the radioactivity measurements was conducted in the spring (April and May 1989 and 1990). To obtain net-balance measurements corresponding to budget years, the current winter snow depth was measured at every pit in order to determine the 1988 and 1989 ablation surfaces. The winter snow depths, which are given in Table 1 (A in column 6), are not taken into account in the balance of the following periods of 3 years (1986-89) and 26 years (1962-88). Therefore, in Table 2 and Figure 5, the periods given correspond to 3 or 26 budget years.

\subsection{The $1986-89$ balance}

There is consistency between the net-balance results of both the direct measurements and using the Chernobyl layer as shown in Figure 3. At the two locations where sampling was made coincidentally with stake measurements (i.e. stations $\mathrm{F}$ and $\mathrm{I}$ and stake 9, station $\mathrm{A}$ and stake D2) both results are identical or very close.

Results from ice cores located between stakes complete the data set and demonstrate that the maximum of net accumulation extends in a zone $2.5 \mathrm{~km}$ long from the top of Kongvegen and $7 \mathrm{~km}$ long from the top of Sveabreen. The net accumulation on Sveabreen is higher than on Kongsvegen (see Fig. 3) and the ELA is around $520 \mathrm{~m}$ a.s.l. for Kongsvegen and $450 \mathrm{~m}$ a.s.l. or a little lower for Sveabreen. Stratigraphic profiles at station $\mathrm{G}$ on Kongsvegen ( $562 \mathrm{~m}$ a.s.l.) indicate that the total net

Table 3. Compared mean net balances of Kongsvegen and Broggerbreen

\begin{tabular}{|c|c|c|c|c|c|c|c|}
\hline \multirow{2}{*}{. } & \multicolumn{3}{|c|}{$\begin{array}{c}b n \\
\text { m w.eq. }\end{array}$} & \multicolumn{4}{|c|}{$\begin{array}{c}b n \\
\text { annual average in mw.eq }\end{array}$} \\
\hline & $1986-87$ & $1987-88$ & 1988-89 & 1987-89 & $1986-89$ & $1967-89$ & $\begin{array}{l}1962-88 \\
1964-90\end{array}$ \\
\hline Brøggerbreen & 0.22 & -0.52 & -0.45 & -0.49 & -0.25 & -0.43 & \\
\hline Kongsvegen & 0.54 & -0.05 & -0.15 & -0.10 & 0.11 & & -0.10 \\
\hline
\end{tabular}




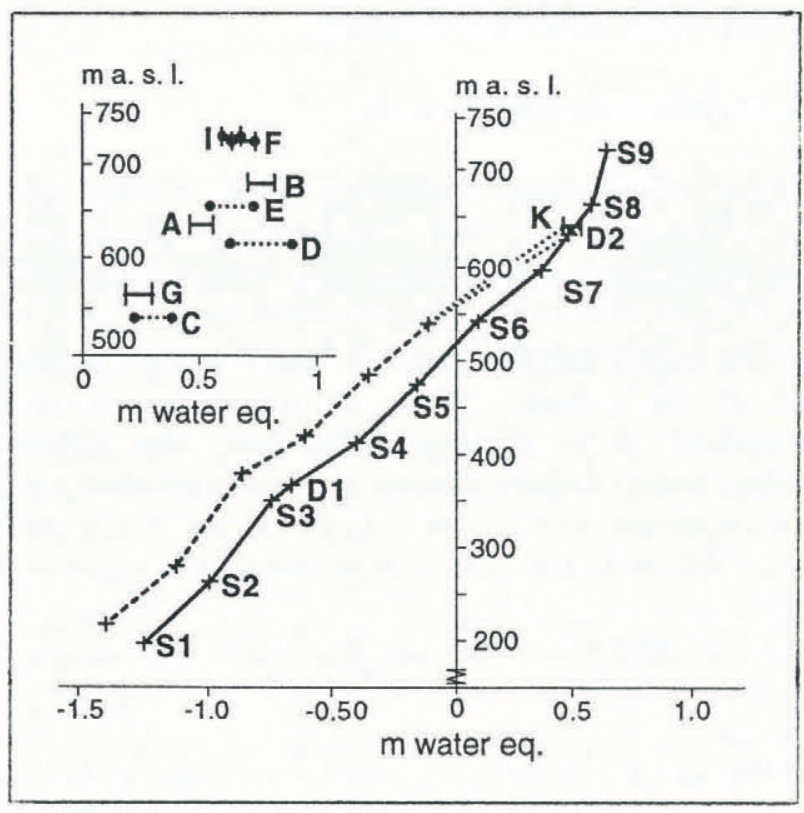

Fig. 3. Mean net balance on Kongsvegen and Sveabreen. The heavy line shows the mean net balance of Kongsvegen during the period 1986-89 using the direct glaciological method. S1, S2 ...S9, D1 and D2 are ablation stakes on the glacier surfaces. The dotted line shows the average for the 26years' period 1964-90, based on geodetic work in the ablation area of Kongsvegen connected to the mean balance estimated at station $K$ by radioactive analysis for the 26 years' period 1962-88. Inset is shown the range of netaccumulation values during the period 1986-89 obtained from the Chernobyl layer. The letters refer to the ice cores described in the text: $(I)$ and $(F)$ are located at Kongsvegpasset in the common accumulation area of the two glaciers; $B, A$ and $G$ with heavy lines and $C, D$ and $E$ with dotted lines are located on Kongsvegen and Sveabreen, respectively.

accumulation is composed of superimposed ice, while at station C on Sveabreen ( $538 \mathrm{~m}$ a.s.1.) the accumulation comprised both firn and ice lenses down to a depth of $6.80 \mathrm{~m}$. This asymmetry of the two accumulation areas has also been observed by Korolev and others (1988). The maximum of net accumulation reflects the winter-balance distribution (see Fig. 4), especially on Sveabreen. Meteorological records at $\mathrm{Ny}$-Ålesund and Longyearbyen, the two closest stations, indicate that snow precipitation occurs mainly with the winter prevailing winds from the southeast sector. This may explain the high rate of snow deposition on the windward Sveabreen and its higher net balance in the accumulation area.

For the period 1986-89, the balance for Kongsvegen was slightly positive ( $\mathrm{bn}=0.11 \mathrm{~m}$ w.eq.) and the ELA at $520 \mathrm{~m}$ a.s.l. (see Fig. 3). This ELA corresponds to an accumulation-area ratio of 0.67. On Sveabreen, for the same period, an ELA of $450 \mathrm{~m}$ a.s.l. corresponds to an accumulation-area ratio of 0.6 but, because of the higher accumulation value on Sveabreen, the balance of this glacier for the 3 analysed years would also have been very close to the equilibrium when the calving is ignored.

\subsection{The $1962-88$ balance}

The net balance on Kongsvegen can be estimated using

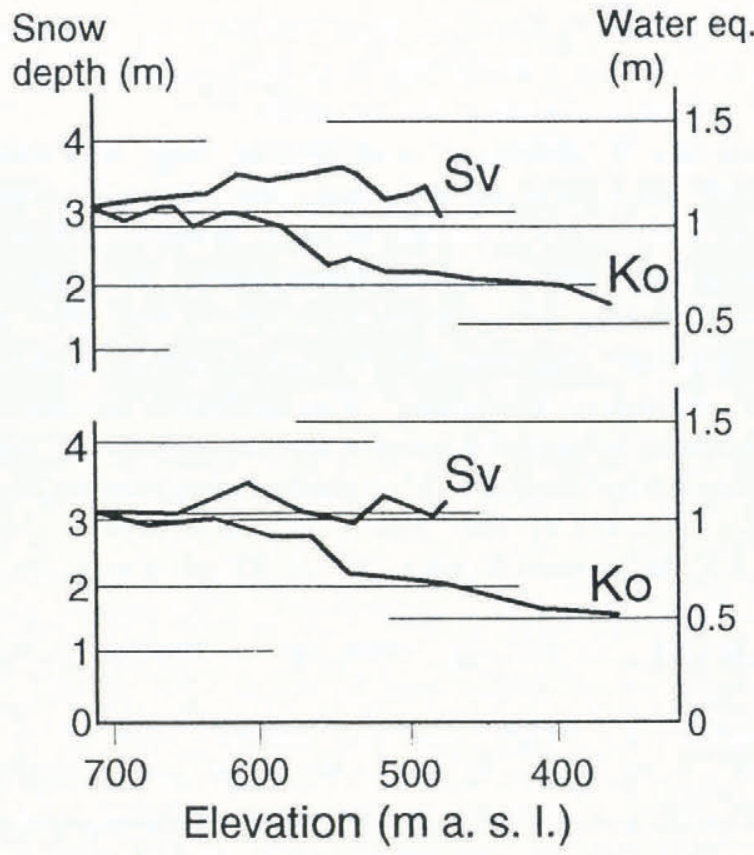

Fig. 4. Relationship between winter accumulation and altitude on Kongsvegen ( $K_{0}$ ) and Sveabreen (Sv) in May 1991 (upper curves) and May 1990 (lower curves).

the 1962 radioactive layer in the accumulation area combined with the surface-topographic survey carried out in 1991 in the ablation area. The accumulation value is for the 26 years $1962-88$ and the ablation values are for the 26 years $1964-90$. In the accumulation area of Kongsvegen, at station $\mathrm{K}$ (639 $\mathrm{m}$ a.s.l.), the 1962 level is located between 18.75 and $20.65 \mathrm{~m}$ depths. That corresponds, when the snow from the winter 1988-89 is not taken into account, to a minimum total accumulation of $11.28 \mathrm{~m}$ or a maximum of $12.93 \mathrm{~m}$ of water equivalent. Annual mean accumulation is then between 0.43 and $0.50 \mathrm{mw}$.eq. for the 26 years of the period $1962-88$, i.e. slightly lower than the mean net accumulation for the years 1986-89 obtained from ice core A (between 0.45 and $0.52 \mathrm{mw} . e q$.$) or by direct annual measurements$ (0.48 m w.eq.).

In the ablation area, the net-balance values can be estimated from geodetic work for the period 1964-90. Pillewizer (1967) carried out a topographic survey on the tongue of Kongsvegen in 1962 and 1964. He constructed a map at a scale of 1:50000 with a contour interval of $10 \mathrm{~m}$ covering the entire ablation area of the glacier. Positions and altitudes of the ten stakes (S1 ... S9 and D2) located on the central axis of the glacier were surveyed in spring 1991, and the altitude of the ablation surface in 1990 was determined. In the ablation area, the net ablation corresponds to a lowering of the surface multiplied by 0.9 , the mean ice density. The ice flow is slow and almost constant along the area. Melvold (1992) has measured movements between 0.72 and $0.81 \mathrm{~cm} \mathrm{~d}^{-1}$ for stakes $1-6$. Owing to a fairly constant slope of $2.5 \%$ and a constant velocity, the unknown vertical flow component may be neglected. At each stake, the change in altitude of the ice surface between 1964 and 1990 has been calculated and counted as the net ablation for the 26 years. The results (see Fig. 3 ) are the mean annual values for the 26 years plotted versus the mean altitudes for the period 1964-90. The result is remarkably parallel 
to the curve obtained from direct measurement during the period 1986-89. Long-term stability of mass-balance gradient has been noted by various authors (Meier and Tangborn, 1965) and has been used as the basis of a linear model (Lliboutry, 1974). From the values obtained, an annual net ablation of $-34.70 \times$ $10^{6} \mathrm{~m}^{3}$ w.eq. can be calculated for the 26 years' period 1964-90. In the accumulation area, the total accumulation must be estimated from the single-range value in the core at point $\mathrm{K}$ (between 11.28 and $12.93 \mathrm{~m}$ w.eq.). From the maximum and minimum values at this point, extrapolation of the mean accumulation curve obtained by direct measurements in the years $1986-89$ and plotted in Figure 3, gives an accumulation between 22.2 and $26.7 \times 10^{6} \mathrm{~m}^{3}$ w.eq. That corresponds to an approximate mean net balance of between -0.13 and $-0.08 \mathrm{~m}$ w.eq. and an ELA around 550-560 $\mathrm{m}$ a.s.1.

In the accumulation area of Sveabreen for the same 26 year period, extrapolation gives a total mean net accumulation of between 31.9 and $44.8 \times 10^{6} \mathrm{~m}^{3}$ w.eq., i.e. much greater than on Kongsvegen. The ELA was around $480 \mathrm{~m}$ and the accumulation-area ratio only 0.52 . The ablation and calving rates are not known. Hence, in spite of the fact that the net accumulation on Sveabreen is higher than on Kongsvegen, Sveabreen more than likely had a negative balance.

In Svalbard, the change in net balance from year to year is well correlated with climatic parameters and is consistent between all surveyed glaciers (Hagen and Liestøl, 1990; Lefauconnier and Hagen, 1990). The present results may be compared with the change in balance from Brøggerbreen (see Table 3) which has been surveyed since 1967. During the 2years 1987-89 for which the Kongsvegen balance has been the same as the estimated mean net balance for the 26 year period $(-0.10 \mathrm{~m}$ w.eq. $)$, the Brøggerbreen balance was lower (although very slightly) than its mean value since 1967. We may conclude that Kongsvegen had effectively a mean net balance near $-0.10 \mathrm{~m}$ w.eq., i.e. not far from equilibrium. The comparison also confirms, for the recent 3 year period, a more positive balance than during the longer period. Such a situation may have been caused by the slight change in climate towards a positive balance that has been detected for Brøggerbreen since 1967 (Lefauconnier and Hagen,1990).

\section{CONCLUSION}

Information on the mass balance of the glacier complex Kongsvegen and Sveabreen has been obtained by using radioactive layers identified in shallow ice cores. Evidence of the Chernobyl (1986) and Novaya Zemlya (1961-62) events is given by the presence of ${ }^{134} \mathrm{Cs}$ and ${ }^{137} \mathrm{Cs}$. It has been found that the natural total $\beta$ radioactivity is about 10 times the artificial radioactivity from the Chernobyl event. The Chernobyl layer has been found in all ice cores. The Novaya Zemlya layer has been found at one location (in the deepest ice core). On the basis of these determinations, an estimate of the mean net balance in the accumulation area for the 3 year period $1986-89$ on both glaciers has been made. These results are consistent with direct measurements on Kongsvegen during the same period. Moreover, the mean net accumulation for the 26 years' period $1962-88$ has also been determined and shows a consistent link with the net ablation for the 26 years' period 1964-90 obtained by topographic work. For the 3 year period 1986-89, the Kongsvegen balance was positive ( $\mathrm{bn}=0.11 \mathrm{mw}$.eq.), while during the period 1962-64 until 1989-90 the balance was slightly negative ( $b n=-0.10 \mathrm{~m}$ w.eq., approximately). Sveabreen, for which the calving rate is not taken into account, had a balance close to zero during the period 1986-89 and a negative one during the period 1962-88.

The present work shows that a new reference horizon resulting from the Chernobyl accident (1986) has been detected on Svalbard glaciers and that the already known Novaya Zemlya 1961-62 layer has also been detected. The discovery of these reference levels enables the determination of the net accumulation on glaciers located in remote areas in the Northern Hemisphere during a single field season. These horizons can also be used to obtain the balance when complementary information is available. By drilling a deeper ice core (in Svalbard around $35 \mathrm{~m}$ ), it will be possible to reach layers deposited prior to the first atmospheric thermonuclear test in 1953. Detection of three reference horizons will allow comparison of net-accumulation values during three different periods. This method may be used only on glaciers having an accumulation area at a significant level above the equilibrium line and limited percolation in the highest part of their basins. Extension of the work to other glaciers in Svalbard will serve the increasing interest in glacier-balance studies.

\section{ACKNOWLEDGEMENTS}

This work was funded by the E.C. under the EPOC 0035 program. The field work was possible by a grant from the French-Norwegian Foundation for Research and Technologic Development. We express also our gratitude to Professor M. Vallon for helpful discussions and Professor M. Durand from the French Embassy in Oslo for his continuing support.

\section{REFERENCES}

Ambach, W., W. Rehwald, M. Blumthaler, H. Eisner and P. Brunner. 1987. Radioactive fallout on Alpine glaciers from the Chernobyl nuclear accident. Z. Gletscherkd. Glazialgeol., 23(2), 123-129.

Ambach, W., W. Rehwald, M. Blumthaler, H. Eisner and P. Brunner. 1989. Vertical dispersion of Chernobyl fall-out on Kesselwandferner, Oetztal Alps, Austria. J. Glaciol., 35(120), 294.

Davidson, C. I., J. R. Harrington, M.J. Stephenson, M. C. Monaghan, J. Pudykiewicz and W. R. Schell. 1987. Radioactive cesium from the Chernobyl accident in the Greenland ice sheet. Science 237(4815), 633-634.

Delmas, R. and M. Pourchet. 1977. Utilisation de filtres échangeurs d'ions pour l'étude de l'activité $\beta$ globale d'un carottage glaciologique. International Association of Hydrological Sciences Publication 118 (Symposium at Grenoble 1975-Isotopes and Impurities in Snow and Ice), 159-163.

Dibb, J. 1989. The Chernobyl reference horizon (?) in the Greenland ice sheet. Geophys. Res. Lett., 16(9), 987-990.

Haeberli, W., H. Gäggeler, U. Baltensperger, D. Jost and U. Schotterer. 1988. The signal from the Chernobyl accident in high-altitude firn areas of the Swiss Alps. Ann. Glaciol., 10, 48-51. 
Hagen, J. O. and O. Liestøl. 1990. Long-term glacier mass-balance investigations in Svalbard 1950-88. Ann. Glaciol., 14, 102-106.

Hanssen-Bauer, I., M. Kristensen Solås and E. L. Steffensen. 1990. The climate of Spitsbergen. Klima (Det Norske Meteorologiske Institutt). Rapport 39/90.

Holdsworth, G., M. Pourchet, F. A. Prantl and D. P. Meyerhof. 1984. Radioactivity levels in a firn core from the Yukon Territory, Canada. Atmos. Environ., 18(2), 461-466.

Korolev, P.A., S. A. Sin'kevich and A.V. Tarusov. 1988. Stroyeniye firnovoy tolshchi lednikov Svea-Kongsvegen na a Zapadnyy Shpitsbergen i ikh glyatsiologicheskaya zonal'nost' [The structure of the firn sequence of the Svea-Kongsvegen glaciers on Spitsbergen and their glaciological zonation]. Mater. Glyatsiol. Issled. 64, 78-83.

Lefauconnier, B. and J.O. Hagen. 1990. Glaciers and climate in Svalbard: statistical analysis and reconstruction of the Broggerbreen mass balance for the last 77 years. Ann. Glaciol., 14, 148-152.

Lliboutry, L. 1974 Multivariate statistical analysis of glacier annual balances. F. Glaciol., 13(69), 371-392.

Meier, M. F. and W.V. Tangborn. 1965. Net budget and flow of South Cascade Glacier, Washington. 7. Glaciol., 5(41), 547-566.

Melvold, K. 1992. Studier av brebevegelse på Kongsvegen og Kronebreen. (M.Sc. thesis, University of Oslo.)

Pillewizer, W. 1967. Die wissenschaftlichen Ergebnisse der deutschen Spitzbergenexpedition, 1964-1965. Geodätische und Geophysikalische Veröffentlichungen, Reihe II, Heft 12.

Pinglot, J.F. and M. Pourchet. 1979. Low level beta counting with an automatic sample changer. Nucl. Instrum. Methods, 166(3), 483-490.

Pinglot, J.F. and M. Pourchet. 1989. Détermination du bilan glaciaire en zone d'accumulation par mesure in situ de la radioactivité due à Tchernobyl. C. R. Acad. Sci., Sér. II, 309(4), 365-370.
Pinglot, J.F., M. Pourchet, B. Lefauconnier and J. O. Hagen. 1992. Chernobyl fallout in Svalbard: glaciological applications. In Proceedings of the French-Norwegian Arctic seminar, Paris, 15-16 October 1992. FNS c/o Norges Teknisk Naturvitenskapelige Forskningsråd, Oslo, 1-14.

Pourchet, M., J.F. Pinglot and J. C. Gascard. 1986. The northerly extent of Chernobyl contamination. Nature, 323(6090), 676.

Pourchet, M., J.F. Pinglot, L. Reynaud and G. Holdsworth. 1988. Identification of Chernobyl fall-out as a new reference level in Northern Hemisphere glaciers. F. Glaciol., 34(117), 183-187.

Punning, Ya. -M. K., T. A. Martma, K. E. Tuygu, R. A. Vaykmyae, M. Purshe [Pourchet] and F. Pinglo [Pinglot]. 1986. Stratification in an ice core from Vestfonna, Nordaustlandet. Polar Geography and Geology, 10, 39-43.

Salvigsen, O., A. Elgersma, C. Hjort, E. Lagerlund, O. Liestøl and N. O. Svensson. 1990. Glacial history and shoreline displacement on Erdmannflya and Bohemanflya, Spitsbergen, Svalbard. Polar Res., 8(2), 261-273.

Steffensen, E. L. 1982. The climate at Norwegian Arctic stations. Klima (Det Norske Meteorologiske Institutt) 5.

Vaykmyae, R.A. and Ya.M.K. Punning. 1989. Stratifikatsiya lednikovykh kernov Shpitsbergena $\mathrm{v}$ tselyakh glyatsioklimaticheskikh rekonstruktsiy [Stratification of ice cores from Spitsbergen with a view to glacioclimatic reconstructions]. Mater. Glyatsiol. Issled. 67, 97-103.

The accuracy of references in the text and in this list is the responsibility of the authors, to whom queries should be addressed. 